\title{
DAMPAK KEBERADAAN KAMPUS UNIVERSITAS TRUNOJOYO MADURATERHADAP NILAI TANAH YANG ADA DI SEKITARNYA
}

\author{
Asri Pratiwi A.S.R ${ }^{1)}$ dan Ihsannudin \\ Program Studi Agribisnis \\ Fakultas Pertanian Universitas Trunojoyo Madura \\ e-mail: asri_pratiwi18@yahoo.com ${ }^{1)}$
}

\begin{abstract}
Development around the campus of University of Trunojoyo Madura continues to grow rapidly along with the increasing number of students in each year. It leads to a competition for a piece of land either. The aims of this study are to know the condition of the land uses after the development of life on the campus of UTM, to know the differences of land values in the campus area of UTM and outside campus area (Non UTM), and to know the factors which affect the land values around the campus area. The Analyzing data which used in this study are descriptive analysis, $t$-Test analysis, and multiple linier regression analysis with dummy. The results of this study show that the land uses around the campus of UTM are for agriculture, residential, boarding house, and business. The highest land value around the campus area is Rp. 2.500.000/ $\mathrm{M}^{2}$, While the highest land value outside campus area (Non UTM) is Rp. 850.000/M ${ }^{2}$. The factors which affect the land values around the campus area are the distance of the land to the main road, the distance of the land to the campus of UTM, legality, topography, and the ground form.
\end{abstract}

Keywords: Land Value, Land Use, The difference of Land Value

\section{PENDAHULUAN}

Jumlah populasi penduduk dunia pada bulan Juli 2015 tercatat sebanyak 7.256.490.001 jiwa. Indonesia menduduki urutan keempat dengan jumlah penduduknya sebanyak 255.993 .674 jiwa atau sekitar $3,5 \%$ dari keseluruhan jumlah penduduk Dunia (CIA,2015). Meningkatnya jumlah penduduk menyebabkan kebutuhan akan tempat tinggal serta sarana-prasana pendukung untuk kegiatan sehari-hari lainnya juga ikut meningkat. Seiring denganmeningkatnhya jumlah penduduk maka akan meningkatkan persaingan untuk mendapatkan sebidang tanah baik untuk pemukiman maupun kegiatan ekonomi (Rahayu, 2009). Tanah didefinisikan sebagai sumberdaya alam dimana semua makhluk hidup menggantungkan kehidupannya (Suparmoko, 2002, dan Sutawijaya, 2004).

Pembangunan sarana dan fasilitas umum membutuhkan tanah, namun permasalahannya adalah ketersedian tanah yang terbatas dan luasnya yang tidak pernah bertambah (Wicaksono, 2012). Keberadaan sarana umum akan meningkatkan nilai tanah yang ada disekitarnya. Menurut Zuhriyah dan Ihsannudin (2013), variabel utama yang menentukan nilai tanah adalah berkaitan dengan jarak ke pusat kota, pusat kegiatan ekonomi dan lokasi tanah yang memiliki aksesibilitas. Aksesibilitas salah satu yang menjadi daya tarik lokasi dikarenakan kemudahan untuk mencapai berbagai pusat kegiatan salah satunya adalah pusat pendidikan, baik pendidikan dasar hingga perguruan tinggi. Adanya fasilitas publik akan merangsang pembangunan disekitarnya. Lebih lanjut 
Setiawan (2006), menyebutkan bahwa faktor yang paling mempengaruhi nilai tanah dan bangunan pada suatu property adalah faktor lokasi yang meliputi letak wilayah yang berada dalam pusat keramaian, tanah dan bangunan yang berada didataran tinggi, serta tanah dan bangunan yang berada didekat pantai, sedangkan faktor yang kurang mempengaruhi yaitu faktor topografi yang meliputi keadaan kountur tanah yang kurang rata, luas dan jenis tanah. Haughwout dkk (2008), menjelaskan bahwa harga property di daerah metropolitan New York cenderung meningkat (10\%-25\%), apalagi dengan adanya perbaikan dan renovasi perumahan dan fasilitas. Sementara Portnov dkk (2005), menjelaskan bahwa faktor lingkungan yang mempengaruhi nilai sebuah property di perumahan di Haifa, Israel.

Universitas Trunojoyo Madura (UTM) merupakan satu-satunya Universitas Negeri yang ada di Madura dan disahkan langsung oleh presiden $\mathrm{KH}$. Abdurahman Wahid dalam keputusan presiden (keppres) RI nomer 85 Tahun 2001. Dibangun diatas tanah seluas 30 hektar di desa Telang Kecamatan KamalBangkalan. Dalam perkembangannya setiap tahun terjadi peningkatan jumlah mahasiswa. Pada tahun 2015 tercatat jumlah seluruh mahasiswa aktif di UTM sebanyak 12.65 jiwa yang terdiri dari beberapa fakultas yaitu: Fakultas Pertanian, Fakultas Ekonomi, Fakultas Hukum, Fakultas Teknik, Fakultas IImu Sosial dan IImuBudaya, Fakultas Keguruan dan IImu Pendidikan, dan yang terakhir Fakultas IImu Keislaman dengan berbagai program diploma, sarjana dan pasca sarjana.

Berdirinya kampus UTM tersebut maka akan mempengaruhi berbagai aspek kehidupan, seperti aspek sosial, budaya dan ekonomi serta nilai tanah di desa Telang. Pesatnya perkembangan bisnis rumah kontrakan/kost, rumah makan, counter handphone,fotocopy, warnet, laundry, bengkel, pertokoan dan lain-lain yang menjadi penyedia fasilitas dan layanan bagi mahasiswa menyebabkan kenaikan nilai tanah di sekitar kampus UTM. Berdasarkan informasi awal menyatakan bahwa setiap tahun terjadi kenaikan nilai tanah, pada tahun 2010 harga tanah di sekitar kampus Universitas Trunojoyo Madura berkisar antara Rp.200.000/meter hingga Rp.500.000/ meter namun pada tahun 2015 harganya naik menjadi Rp.1.300.000/ meter hingga Rp.2.500.000/ meter. Walaupun harga tanah setiap tahun mengalami peningkatan namun pembangunan disekitar kampus UTM ini tetap terus bertambah.

Berdasarkan latar belakang tersebut penelitian ini bertujuan untuk mengetahui: (1); Kondisi pemanfaatan pertanahan setelah berkembangnya kehidupan kampus UTM (2) perbedaan harga tanah di kawasan kampus UTM dan Non UTM;(3) faktor-faktor yang mempengarui perubahan nilai tanah yang ada di sekitar kampus UTM.

\section{METODE PENELITIAN}

\section{Tempat dan Waktu Penelitian}

Penelitian ini dilakukan di daerah sekitar kampus Universitas Trunojoyo Madura desa Telang kecamatan Kamal dimana wilayah tersebut disebut wilayah kawasan UTM, dan desa- desa yang ada di sekeliling Desa Telang. Untuk batas selatan desa telang adalah desa gili timur, batas barat adalah desa gili anyar, batas utara adalah desa buluh dan batas timur daya adalah desa pandabah. Keempat desa tersebut merupakan desa yang menjadi daerah pembanding perbedaan nilai tanah dimana wilayah tersebut tergolong wilayah kawasan non UTM. Pemilihan wilayah secara sengaja (purposive) dengan melakukan pertimbangan bahwa lokasi tersebut tidak terkena dampak langsung dari 
berdirinya Universitas Trunojoyo Madura. Pengambilan data dilakukan pada Januari - Februari 2016.

\section{Jenis dan Sumber Data}

Dalam penelitian ini jenis data yang digunakan ada 2 yaitu data primer dan data sekunder. Data primer diperoleh secara langsung dari sumber asli dengan cara: 1) Observasi yang digunakan untuk menjawab permasalahan pertama pada penelitian ini terkait dengan penggunaan tanah disekitar kampus UTM. Selain itu, juga digunakan untuk mendapatkan informasi terkait variabel lokasi yang meliputi pengukuran jarak bidang tanah ke jalan raya, jarak bidang tanah ke kampus UTM, jarak bidang tanah kepasar, topografi, legalitas, dan bentuk tanah serta untuk melihat penggunaan tanah di sekitar UTM yang di ukur dengan alat bantuan google map. 2) Wawancara (interview) yang dilakukan secara langsung dengan menggunakan kuisioner guna memperoleh informasi terkait dengan harga tanah baik dengan responden baik di daerah sekitar UTM dan non UTM.

Sedangkan data sekunder diperoleh dari dokumen dinas pemerintahan Kabupaten Bangkalan, seperti Badan Pusat Statistik (BPS), Badan Pertanahan Nasional (BPN), Kantor Pelayanan dan Perijinan Terpadu (KPPT), dan Badan Perencanaan Pembangunan Daerah (Bappeda).

\section{Metode Penentuan Sampel}

Penentuan responden dalam penelitian ini dilakukan secara purposive sampling (sengaja). banyaknya responden dalam penelitian ini adalah 80 responden. 40 responden berasal dari sekitar UTM dan 40 responden pada wilayah non UTM.

Menurut sanusi (2013), mengatakan bahwa untuk penelitian sebab akibat minimal 30 responden sudah dianggap mewakili jumlah populasi yang ada. Ruslan (2008), penentuan ukuran responden yang diambil pada masing-masing desa dapat dilakukan dengan mencari nilai rata-rata menggunakan persamaan sebagai berikut:

Spl $=\frac{\mathrm{n}}{\mathrm{N}} \mathrm{Xjs}$

Dimana $\mathbf{S p l}=$ sampel, $\mathbf{n}=$ jumlah responden, $\mathbf{N}=$ total responden, Js=besar sampel

Dari rumus diatas dapat ditentukan jumalah responden masing-masing desa pada tabel 1.

Tabel 1

Jumlah responden masing-masing desa

Desa Populasi penduduk Jumlah responden

\begin{tabular}{ccc}
\hline Gili anyar & 3064 & 8 \\
Gili timur & 3191 & 8 \\
pandabah & 3621 & 10 \\
buluh & 5077 & 14 \\
total & 14.953 & 40 \\
\hline
\end{tabular}

Sumber:data BPS Bangkalan Diolah,2014 


\section{Metode Analisis data}

Dalam penelitian ini ada 3 metode analisis yang digunakan yaitu, analisis deskriptif, Uji-t independen dan analisis regresi linier berganda dengan menggunakan software SPSS 17.0.

\section{Analisis Deskriptif}

Analisis deskriptif digunakan untuk menjawab rumusan masalah yang pertama. Menjelaskan kondisi pemanfaatan tanah yang terjadi saat penelitian berlangsung di sekitar kampus UTM.

Analisis deskriptif juga digunakan untuk menjelaskan faktor-faktor yang mempengaruhi nilai tanah yang terjadi di daerah sekitar UTM.

\section{Uji-t Independen}

Uji-t dua sampel bebas (independent sample $t$ test) merupakan uji yang membandingkan rata-rata dari dua grup sampel yang tidak berhubungan satu dengan yang lain.

Dasar pengambilan keputusan

- Jika probabilitas $>0,05$, maka $\mathrm{H} 0$ diterima

Hipotesisis:

- Jika probabilitas $<0,05$, maka H0 ditolak.

$\mathrm{HO}$ :Tidak terdapat perbedaan yang signifikakan antara nilai tanah di daerah sekitar kampus UTM dengan daerah non UTM

$\mathrm{H} 1$ :Terdapat perbedaan yang signifikakan antara nilai tanah di daerah sekitar kampus UTM dengan daerah non UTM.

\section{Analisis Regresi Dengan Dummy}

Regresi merupakan salah satu dari berbagai macam alat analisis yang biasanya digunakan untuk melihat seberapa jauh perubahan nilai variabel dependen, bila nilai variabel independen dirubah. Menurut Sugiono (2012) manfaat dari analisis regresi yaitu untuk membuat keputusan apakah variabel independen yang digunakan dapat menaikkan atau menurunkan variabel dependen. Seperti yang dipaparkan oleh Siregar (2005), bahwa regresi merupakan analisis tentang hubungan antara variabel tak bebas atau penjelas (dependen variable) dengan variabel bebas atau penjelas (independent variable). selain variabel dependen dan independen dalam analisis regresi juga terkadang ada yang disebut dengan variabel dummy. Santoso (2014), menyatakan bahwa variabel dummy merupakan variabel yang digunakan untuk membuat kategori data yang bersifat kualitatif (nominal)

Dalam penelitian ini yang menjadi variabel dependen adalah harga tanah, sedangkan variabel independennya adalah luas tanah, jarak bidang tanah dengan jalan raya, jarak bidang tanah dengan kampus UTM, jarak bidang tanah dengan pasar, status legalitas tanah, bentuk tanah dan topografi tanah. Status legalitas tanah, bentuk tanah, dan topografi tanah merupakan variabel dummy. Dari varibel-variabel diatas maka dapat dituliskan rumus sebagai berikut:

$\operatorname{LnY}=a+\operatorname{Lnb}_{1} X_{1}+\operatorname{Lnb}_{2} X_{2}+\operatorname{Lnb}_{3} X_{3}+\operatorname{Lnb}_{4} X_{4}+b_{5} D_{5}+b_{6} D_{6}+b_{7} D_{7}+e$

DimanaY $=$ Harga tanah $\left(R p / m^{2}\right)$, a = Konstanta, $X_{1}=$ Luas tanah $\left(\mathrm{m}^{2}\right)$, $\mathbf{X}_{\mathbf{2}}=$ Jarak bidang tanah dengan jalan raya (meter), $\mathbf{X}_{\mathbf{3}}=$ Jarak bidang tanah dengan kampus UTM (meter), $\mathbf{X}_{4}=$ Jarak bidang tanah dengan pasar (meter), $\mathbf{D}_{5 \text { - }}$ $=$ status legalitas tanah (dummy) 1 ; sudah ada sertifikat, 0 belum ada, $\mathbf{D}_{6}=$ Bentuk tanah (dummy)1; jika persegi panjang, 0 ; lainnya, $\mathbf{D}_{\mathbf{7}}=$ Topografi tanah 
(dummy)1; datar, 0:lainnya, $\mathbf{b}_{1}-\mathbf{b}_{7}=$ koefisien regresi, $\mathbf{e}=$ error.

Dalam analisis regresi, harus memenuhi asumsi klasik atau yang disebut dengan Ordinary Least Square (OLS) untuk mendapatkan nilai-nilai koefisiennya tidak bias (Santoso, 2014). Asumsi klasik tersebut terdiri dari normalitas, linieritas, autokorelasi, multikolonieritas dan heterokidastisitas dan autokorelasi.

1. Uji Normalitas, Tujuan dari uji normalitas adalah untuk mengetahui suatu data berdistribusi normal atau tidak (Santoso 2014). Untuk pengambilan keputusan dengan melihat tabel kolmogorov-smimov, jika nilai sig >0,05 maka data tersebut dapat dikatakan berdistribusi normal, sedangkan apabila nilai sig < 0,05 maka data tersebut tidak berdistribusi normal.

2. Uji Linieritas, Tujuan dari uji untuk mengetahui suatu data yang akan dianalisis sesuai dengan garis linier atau tidak. Dasar pengambilan keputusan dengan melihat nilai dari Deviation Form Linearity. Jika nilai sig > 0,05 maka dikatakan hubungan antar variabel linier dan sebaliknya (sarjono dan winda 2011).

3. Uji Multikolonieritas, pengujianini dengan melihat nilai Variance Inflating Factor (VIF) dari hasil analisis regresi. Pengujian ini dilakukan dengan mengukur korelasi antar variabel independen. Apabila variabel-variabel independen terbukti berkorelasi secara kuat, maka dapat dinyatakan bahwa terdapat multikolinieritas pada variabel-variabel tersebut. Jika VIF $<10$ maka dapat disimpulkan data tidak terkena multikolonieritas (Sarjono dan Sinda 2011).

4. Uji Heterhokedastisitas, digunakan untuk memastikan apakah dalam model regresi terdapat ketidaksamaan varians residual antara satu pengamatan ke pengamatan yang lain. Apabila masing-masing variabel bebas tidak berpengaruh signifikan terhadap nilai residual $(\alpha=0.05)$ maka dalam model regresi tidak terjadi gejala heterhokedastisitas (Sarjono dan Winda 2011).

5. Uji Autokorelasi, merupakan korelasi antra anggota sampel uang diurutkan menurut waktu (seperti dalam data time series) dan ruang (seperti dalam data crossection) (Gujarati, 1978). Menurut Santoso 2014, pengujian autokorelasi dilakukan dengan uji Durbin-Wiston. Dengan kriteria pengambilan keputusan sebagai berikut:

- Jika D-W <-2 artinya ada autokorelasi positif

- Jika D-W di antara -2 sampai +2 artinya tidak ada autokorelasi

- Jika D-W >+2 artinya ada autokorelasi negatif

Sarjono dan Winda 2014, menambahkan selain menggunakan uji Darbin-

Wiston, pengujian autokorelasi bisa menggunakan Uji Run Test, uji Langrage Multiplier (LM) dan uji Statitik Q. Dalam penelitian ini, mengunakan Uji Run Test untuk melihat apakah data resedual bersifat random atau tidak (sistematis).Kriteria penganmbilan keputusan:

- Jika Asymp. Sig >0,05 bebas autokorelasi

- Jika Asymp. Sig <0,05 terdapat autokorelasi

Setelah melakukan uji asumsi klasik rangka selanjutnya melakukan uji statistik agar mendapatkan model regresi yang baik maka harus memenuhi kriteria statistik yang terdiri dari uji koefisien determinan $\left(R^{2}\right)$, uji secara simultan (uji F) dan uji koefisien secara parsial (uji T).

\section{Uji koefisien determinan $\left(\mathbf{R}^{2}\right)$}

Nilai koefisien determinan $\left(R^{2}\right)$ mempunyai range antara $0-1$. Persamaan regresi berganda semakin baik apabila nilai determinan $\left(R^{2}\right)$ semakin besar 
(mendekati 1) dan meningkat nilainya sejalan dengan peningkatan variabel bebas. Sedangkan apabila nilai koefisien determinan $\left(R^{2}\right)$ semakin kecil (mendekati 0) maka variabel independen secara keseluruhan tidak bisa menjelaskan variabel independen dan variabel dinyatakan tidak layak.

\section{Uji secara simultan (uji F)}

Digunakan untuk melihat apakah variabel independen secara bersama-sama mempengaruhi variabel dependen. Dasar pengambilan keputusan apabila $F_{\text {hitung }}$ $<F_{\text {tabel }}$ maka variabel independen tidak berpengaruh secara simultan terhadap variabel dependen, sedangkan apabila $F_{\text {hitung }}>F_{\text {tabel }}$ maka variabel independen berpengaruh secara simultan terhadap variabel dependen. Selain membandingkan nilai $F_{\text {hitung }}$ dan $F_{\text {tabel }}$ dapat juga menggunakan nilai sig. Apabila nilai sig $<0.05$ maka variabel independen berpengaruh secara simultan terhadap variabel dependen.

\section{Uji secara parsial ( $u j i t)$}

Digunakan untuk melihat apakah variabel independen mempengaruhi variabel dependen secara parsial. Dasar pengambilan keputusan yaitu apabila $t_{\text {hitung }}<t_{\text {tabel }}$ maka variabel independen tidak berpengaruh secara parsial terhadap variabel dependen, sedangkan apabila $t_{\text {hitung }}>t_{\text {tabel }}$ maka variabel independen berpengaruh secara parsial terhadap variabel dependen, atau juga bisa menggunakan nilai sig $<0.05$ maka variabel independen berpengaruh secara parsial terhadap variabel dependen.

\section{HASIL DAN PEMBAHASAN}

\section{Penggunaan Tanah di Desa Telang}

Pengembangan kawasan di Kecamatan Kamal lebih disebabkan dengan adanya Universitas Trunojoyo Madura dan kawasan pelabuhan. Sebelum dibangunya jembatan suramadu, biasanya ramai oleh aktifitas masyarakat masyarakat yang ingin menyebrang baik dari Surabaya-Madura dan sebaliknya. Sementara pusat pendidikan di Kecamatan Kamal terletak di desa Telang. Meneurut Bappeda Kabupaten Bangkalan 2015, Desa Telang merupakan kawasan desa terpadu dengan adanya kawasan pendidikan sebesar 21,35 $\mathrm{Ha}$. Jumlah bangunan di desa Telang mencapai 354 unit, rumah semi permanen sebanyak 34 unit dan kontemporer sebanyak 25 unit dengan KDB rata-rata 85\% dengan RTH >20\%,RP2KP/SPPIP (2014). Sedangkan jumlah perumahan yang tertulis pada buku laporan akhir Bapedda Kabupaten Bangkalan 2015 pada Bappeda dapat dilihat pada tabel 2:

\begin{tabular}{cc}
\multicolumn{2}{c}{ Tabel 2} \\
Nama-Nama Perumahan \\
\hline \multicolumn{1}{c}{ Nama } & Luas $\left(\mathrm{M}^{2}\right)$ \\
\hline Perumahan Telang Indah & 1.750 \\
Perumahan Puri Telang & 18.895 \\
Perumahan Graha Trunojoyo & 3.900 \\
Tanah Kavling siap bangun & 34.645 \\
\hline Sumber:laporan Akhir Bapedda Kabupaten Bangkalan 2015.
\end{tabular}

Sementara itu menurut balai penyuluhan Kecamatan Kamal 2015 potensi tanah pertanian adalah sebagai berikut: 
Tabel 3

Luas Wilayah Pertanian Berdasarkan Jenis Penggunaan Tanah (Ha)2013

\begin{tabular}{cc}
\hline \multicolumn{1}{c}{ Penggunaan Tanah } & Luas $(\mathrm{Ha})$ \\
\hline Tanah Kering & \\
$-\quad$ Tegal/ladang & 283,88 \\
$-\quad$ Pekarangan & 118,36 \\
Tanah sawah menurut jenis irigasi & 75 \\
$-\quad 1 / 2$ teknis & 184,5 \\
$-\quad$ Tadah hujan & 301,30 \\
Tambak & 661,74 \\
\hline Jumlah total &
\end{tabular}

Sumber:BPK Kecamatan Kamal 2015

Selain dari segi pertanian, desa telang juga sangat memiliki prospek yang besar dari segi ekonominya. Berdasarkan data observasi kegiatan ekonomi dapat di kategorikan sebagai berikut:

Tabel 4 Jumlah Jenis Usaha Dari Kategori Usaha

\begin{tabular}{llc}
\hline \multicolumn{1}{c}{ Katagori Usaha } & \multicolumn{1}{c}{ Jenis Usaha } & Jumlah \\
\hline Kuliner & Rumah Makan & 1 \\
& Cafe & 4 \\
Jasa & Warung & 20 \\
& Print \& foto copy & 11 \\
& warnet & 3 \\
& Rental PS & 2 \\
& Potong-rambut & 2 \\
& salon & 2 \\
& bengkel & 2 \\
& Mini market & 2 \\
& Potong rambut & 2 \\
& Depo isi ulang air & 2 \\
& Toko/kelontongan & 20 \\
& Toko busana & 1 \\
& Lembaga bimbel & 1 \\
& Laundry & 5 \\
& Counter & 4 \\
& Bank & 1 \\
\hline
\end{tabular}

Sumber:data Primer diolah, 2016

Jenis usaha yang paling banyak selain yang tercantum di atas adalah jasa kos-kosan. Mengingat jumlah mahasiswa UTM setiap tahunnya semakin banyak, sehingga saat ini usaha kos-kosan masih menjadi primadona diantara usaha yang lain. Menjamurnya kos-kosan di desa telang ibarat jamur jamur di musim hujan. Tidak sedikit lahan pertanian yang di alih fungsikan menjadi usaha kos-kosan ini. Namun, berdasarkan informasi yang di peroleh dari Kantor pelayanan dan perijinan terpadu (KPPT) Bangkalan baru ada 9 yang memiliki ijin usaha kos. Selain dari segi pertanian dan ekonominya, desa Telang juga memiliki sarana serta fasilitas umum yang cukup memadai seperti yang terlihat pada tabel 5 berikut ini: 
Tabel 5

Sarana dan Fasilitas Umum

\begin{tabular}{lc}
\hline \multicolumn{1}{c}{ Sarana dan fasilitas umum } & Jumlah \\
\hline Pendidikan & 10 \\
Mesjid & 2 \\
ATM & 6 \\
Halte & 1 \\
\hline
\end{tabular}

Sumber:data Primer diolah, 2016

Ketersediaan fasilitas umum yang merupakan sarana penunjang sengaja di bangun untuk memberikan kemudahan dalam memenuhi kebutuhan hidup masyarkat yang ada disekitarnya. Menurut Astuti dkk (2015), daya beli tanah di suatu wilayah atau zona akan semakin tinggi yang menyebabkan perubahan harga tanah yang semakin tinggi pula yang disebabkan karena wilayah tersebut memiliki fasilitas umum yang lengkap.

\section{Perbedaan Nilai Tanah di Kawasan Kampus UTM dan Non UTM}

Untuk mengetahui perbedaan harga tanah di kawasan kampus UTM dan Non UTM dilakukan dengan cara membandingan nilai tanah melalui uji-t independen dimana sampel dan perlakuan di setiap wilayah itu berbeda. Adapun hipotesisnya adalah sebagai berikut:

$\mathrm{HO} \quad=$ tidak terdapat perbedaan yang signifikan nilai di kawasan kampus UTM dan non UTM

$\mathrm{H} 1=$ Terdapat perbedaan yang signifikan nilai tanah di kawasan kampus UTM dan non UTM

Untuk melihat signifikasinya dapat dilihat pada nilai sig dan $\mathrm{t}$ hitungnya. Apabila nilai Bila sig $>0.05$ maka Ho diterima Bila nilai sig $<0.05$ maka H1

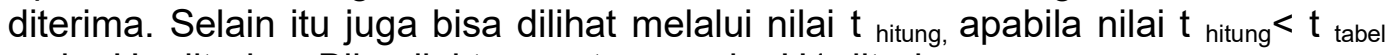
maka Ho diterima Bila nilai $\mathrm{t}_{\text {hitung }}>\mathrm{t}$ tabel maka $\mathrm{H} 1$ diterima.

Menurut Ghozali (2013), sebelum menganalisis apakah terdapat perbedaan nilai rata-rata secara signifikan dengan melihat nilai t-test, terlebih dahulu harus mengetahui apakah variance dari kedua sampel tersebut sama (equal variance assumed) ataukah berbeda (equal variances not assumed) dengan cara melihat nilai levene test.

Adapun hipotesis untuk mengetahui apakah variance populasi sama atau tidak adalah sebagai berikut:

- HO : varian populasi di sekitar kampus UTM dan non UTM adalah sama

- H1 : populasi di sekitar kampus UTM dan non UTM adalah berdeda

Dengan kriteria pengambilan keputusan:

Jika probabilitas $>0,05$, maka menerima $\mathrm{HO}$

Jika probabilitas $<0,05$ maka $\mathrm{HO}$ ditolak

Selanjuatnya melakukan uji t-independen dengan kriteria pengambilan keputusan:

- Jika probabilitas $>0,05$, maka H0 diterima

- Jika probabilitas <0,05, maka HO ditolak.

Hasil analisis Uji t- Independen dapat dilihat pada tabel 6 berikut ini. 
Tabel 6

Perbedaan Harga Tanah Rata-Rata

\begin{tabular}{cc}
\hline Wilayah & Mean \\
\hline Wilayah penelitian & 1.325 .625 \\
Wilayah kontrol & 201.575 \\
\hline
\end{tabular}

Sumber: Data Primer Diolah,(2016)

Dari hasil analisis diketahui bahwa rata-rata harga tanah pada sekitar UTM adalah Rp 1.325.625 sedangkan di daerah non UTM hanya Rp. 201.575. Jelas terlihat adanya perbedaan yang sangat jauh. Harga tertinggi di daerah sekitar UTM adalah Rp 2.500.000 sedangkan harga terendah adalah Rp 400.000, sementara harga tertinggi di daerah non UTM adalah Rp. 850.000 dan terendah adalah $\mathrm{Rp} 50.000$.

Tabel 7

Hasil Analisis Uji t-Independen

\begin{tabular}{ccc}
\hline & Item Pengukuran & Nilai \\
\hline & $\mathrm{f}_{\text {hitung }}$ & 43,458 \\
& Sig & 0,000 \\
$\mathrm{t}_{\text {tabel }}$ & $\mathrm{t}_{\text {hitung }}$ & 10,707 \\
\hline
\end{tabular}

Sumber: Data Primer Diolah,(2016)

Untuk melihat perbedaan tersebut terjadi secaranyata atau tidak maka harus melihat hasil output yang kedua (pada lampiran 1). Dari hasil output kedua dapat diketahui bahwa nilai $F_{\text {hitung }}$ sebesar 43,458 dan signifikansi sebesar 0,000 karena probabilitas $<0,05$ maka $\mathrm{H} 0$ ditolak atau sampel memiliki variance yang berbeda. Dengan demikian analisis uji t-independen harus menggunakan asumsi Equal variances not assumed. Diketehui nilai $t_{\text {tabel }}$ sebesar 1,990847036maka $t_{\text {hitung }}>t_{\text {tabel }}(10,707>1,990847036)$ maka menerima $H 1$. Sedangkan apabila dilihat dari nilai signya dapat disimpulkan menerima $\mathrm{H} 1$ juga karena nilai sig $<0,05$ $(0,000<0,05)$. maka dapat dikatakan bahwa Terdapat perbedaan signifikan nilai tanah di kawasan kampus UTM dan non UTM. Hal ini disebabkan karena tanah yang berada di sekirar kampus memberikan aksesibilitas yang lebih mudah untuk menjangkau ke tempat-tempat kegiatan ekonomi dan pendidikan, selain itu tanah yang berada di daerah penelitian juga memiliki prospek nilai yang lebih tinggi karena terletak di dekat Kampus UTM, sehingga dapat dijadikan sebagai investasi jangka panjang. Adhi dkk (2015), pernah melakukan penelitian tentang perbandingan di kecamatan candisari kota semarang dengan membagi suatu daerah menjadi 60 zona, kemudian diketahui bahwa nilai tanah harga terendah sebesar Rp. 549.00,00 pada zona 28 dan harga tanah tertinggi sebesar Rp. 24.575.000 pada zona 30. Pengunaan tanah dengan harga terendah terdapat di kelurahan karang anar gunung dengan dominasi penggunaan tanah adalah sebagai pemukiman (perkampungan) sedangkan harga tanah teringgi terletak disepanjang jalan sultan agung dengan dominasi penggunaan lahan adalah pemukiman, perdagangan, jasa dan perkantoran.

\section{Faktor-Faktor Yang Mempengaruhi Nilai Tanah}

Untuk mengetahui faktor-faktor yang mempengaruhi nilai tanah di kawasan UTM dan Non UTM menggunakan analisis linier berganda 
dengandummy, dengan harga tanah sebagai variabel dependen dan yang menjadi variabel independenya adalah luas tanah, jarak bidang tanah dengan jalan raya, jarak bidang tanah dengan UTM, jarak bidang tanah dengan pasar,legalitas tanah, topografi dan bentuk tanah. Analisis regresi yang baik harus terbebas dari asumsi BLUE maka dari itu perlu melakukan uji asumsi klasik.

Uji asumsi klasik digunakan untuk menentukan variabel apa saja yang terbebas dari asumsi BLUE (Best Linier Unbiased Estimator). Dalam melakukan uji asumsi klasik dapat menggunakan software SPSS 17.0

\section{Uji Normalitas}

Uji normalitas merupakan uji yang digunakan untuk mengetahui apakahvariabel dependen maupun variabel independen berdistribusi secara normal atau tidak. Dalam penelitian ini uji normalitas dilihat dengan menggunakan analisis kolmologrov smimov (k-S). Sebuah variabel dikatakan berdistribusi normal apabila nilai signifikasinya $>0,05$. Model dalam penelitian ini nantinya adalah dalam bentuk Ln, maka sebelum melakukan uji asumsi klasik semua data dalam variabel ditransformasikan kedalam bentuk Ln. Hasil dari analisis kolmologrov dari setiap variabel bisa dilihat pada tabel. 8 berikut ini.

Tabel 8

Uji Normalitas Data

\begin{tabular}{ccc}
\hline Variabel & Sig & Keputusan \\
\hline Ln_Y & 0,575 & Normal \\
Ln_X & 0,512 & Normal \\
Ln_X & 0,079 & Normal \\
Ln_X & 0,525 & Normal \\
Ln_X & 0,274 & Normal \\
\hline
\end{tabular}

Sumber: Data Primer Diolah,(2016)

Dari tabel diatas diketahui bahwa nilai Sing dari masing masing variabel $>$ 0,05 , maka dari itu semua data sudah dapat dikatakan berdistribusi normal.

2. Uji Linieritas

Uji linieritas digunakan untuk mengetahui apakah data yang dimiliki sesuai dengan garis linier atau tidak. Hasil dari uji linieritas dapat dilihat pada tabel 9berikut ini:

Tabel 9

Uji Linieritas

\begin{tabular}{rlc}
\hline Hubungan & Nilai Sig & Keputusan \\
\hline Ln_Y $\rightarrow$ Ln_X & 0,103 & Linear \\
Ln_Y $\rightarrow$ Ln_X & 0,699 & Linear \\
Ln_Y $\rightarrow$ Ln_X & 0,681 & Linear \\
Ln_Y $\rightarrow$ Ln_X & 0,246 & Linear \\
\hline
\end{tabular}

Sumber: Data Primer Diolah,(2016)

Kriteria pengambilan keputusan pada uji linieritas adalah sebagai berikut:

- Jika Sig pada Deviation from liniearity >0,05 maka hubungan antar variabel linear 
- Jika Sig pada Deviation from liniearity $<0,05$ maka hubungan antar variabel tidak linear

Dari tabel tersebut terlihat semua hubungan variabel dependen dan independen linear, karena nilai Sig $>0,05$.

3. Uji Multikolonieritas

Uji ini digunakan untuk mengetahui apakah pada model regresi ditemukan adanya korelasi antar variabel independen. Model regresi yang baik seharusnya tidak terjadi korelasi antar variabel dependen. Dalam penelitian ini multikolieniritas dilihat dari nilai VIF (variance-inflating factor), jika nilai VIF $<10$ maka dapat dikatakan bebas multikolonieritas atau tingkat korelasi dapat ditoleransi. Hasil dari uji Multikolonieritas dapat dilihat pada tabel 10 berikut ini:

Tabel 10

Uji Multikolonieritas

\begin{tabular}{lr}
\hline Model & Nilai VIF \\
\hline (constan) & \\
Ln_X & \\
Ln_X & 1,056 \\
Ln_X & 4,381 \\
Ln_X & 1,754 \\
\hline
\end{tabular}

a. Dependent Variabel : harga tanah

Sumber: Data Primer Diolah,(2016)

Dari tabel tersebut dapat dilihat bahwa semua variabel telah bebas dari multikolonieritas karena nilai VIFnya $<10$.

4. Uji Heteroskedastisitas

Uji heteroskedastisitas digunakan untuk mengetahui ada tidaknya penyimpangan model regresi yang menyebabkan varian tidak sama dari suatu pengamatan ke pengamatan lainnya. Untuk mendeteksi heteroskedastisitas menggunakan uji gletjer. Adapun nilai sig dari uji gletjer ini dapat dilihat pada tabel 11 berikut:

Tabel 11

Uji Heteroskedastisitas

\begin{tabular}{ll}
\hline Variabel & Nilai Sig \\
\hline Ln_X & 0,091 \\
Ln_X & 0,879 \\
Ln_X & 0,059 \\
Ln_X & 0,468 \\
\hline Sumber: Data Primer Diolah,(2016)
\end{tabular}

Pada tabel 11 terlihat bahwa semua variabel independen bebas dari heteroskedastisitas, karena nilai sig $>0,05$. Selain menggunakan uji gletjer, uji heteroskedastisitas menyebar dan tidak membentuk pola tertentu maka data tersebut dinyatakan bebas heterosdastisitas. 


\section{Uji Autokorelasi}

Uji autokorelasi untuk mengetahui apakah ada gangguan yang berhubungan dengan sampel lain. Pengujian autokorelasi pada penelitian ini menggunakan uji Runs test dengan kriteria pengambilan keputusan sebagai berikut:

- Jika Asymp. Sig > 0,05 bebas autokorelasi

- Jika Asymp. Sig < 0,05 terdapat autokorelasi

Dari hasil analisis SPSS 17.0 di ketahui bahwa nilai Asymp.sig.(2-tailed) sebesar $0.078>0.05$ maka dapat disimpulkan bahwa tidak terdapat autokorelasi antar anggota sampel.

Setelah melakukan uji asumsi klasik, langkah selanjutnya untuk mengetahui faktor-faktor yang berpengaruh terhadap nilai tanah yang ada di sekitar kampus Universitas Trunojoyo Madura dilakukan analisi regresi linier berganda dengan dummy, dengan menggunakan bantuan SPSS 17.0. Variabel dependen dalam penelitian ini adalah harga tanah, sedangkan variabel independennya adalah luas lahan, jarak bidang tanah ke jalan raya, jarak bidang tanah ke UTM, jarak bidang tanah ke pasar yang telah ditransformasi kedalam bentuk Ln serta legalitas, topografi dan bentuk tanah yang menjadi variabel dummy. Adapun hasil output dari hasil analisisnya dapat diketahui pada tabel 12 berikut :

Tabel 12

Hasil Analisis Regresi Linier Berganda dengan Dummy

\begin{tabular}{lrrrr}
\hline Variabel & $\mathrm{B}$ & & \multicolumn{1}{c}{$\mathrm{T}$} & \multicolumn{1}{c}{ Sig } \\
\hline Constant & & 12,072 & 3,157 & 0,003 \\
Ln_X & & 0,001 & 0,012 & 0,991 \\
Ln_X & & $-0,386$ & $-3,493$ & 0,001 \\
Ln_X & & $-0,282$ & $-2,370$ & 0,024 \\
Ln_X & & 0,709 & 1,289 & 0,207 \\
$D_{6}$ & & 0,704 & 7,162 & 0,000 \\
$D_{7}$ & & 0,323 & 3,460 & 0,002 \\
$D_{8}$ & & $-0,260$ & $-2,813$ & 0,008 \\
\hline Adjusted R & & & & \\
$f_{\text {hitung }}^{2}$ & 0,787 & & & \\
$f_{\text {tabel }}$ & 21,615 & & & \\
$t_{\text {tabel }}$ & 2,3127 & & &
\end{tabular}

Sumber: Data Primer Diolah,(2016)

Dari hasil analisis regresi di atas maka model yang didapatkan adalah sebagai berikut:

$$
L n \_Y=12.072-0.386 L n \_X_{2}-0.282 L n \_X_{3}+0.704 D_{5}+0.323 D_{6}-0.260 D_{7}
$$

Maka pengujian hipotesis yang dilakukan adalah sebagai berikut :

a. Koefisien Determinasi $\left(R^{2}\right)$

Koefisien determinasi digunakan untuk mengetahui seberapa besar kemampuan model dalam menjelaskan variabel dependen. Darihasil output SPSS 17.0 diketahui nilai adjusted $\mathrm{R}^{2}$ pada tabel Model Summary yaitu sebesar 0,787 atau $78,7 \%$. Hal ini berarti $78,7 \%$ dampak keberadaan kampus UTM secara bersama-sama dapat dijelaskan oleh delapan variabel independen yaitu luas tanah, jarak bidang tanah dengan jalan raya, jarak bidang tanah dengan UTM, jarak bidang tanah dengan pasar, legalitas, topografi dan bentuk 
tanah.Sedangkan sisanya $21,3 \%$ dijelaskan oleh variabel lain yang tidak dimasukkan ke dalam model.

b. Uji Simultan (uji F)

Untuk mengetahui ada atau tidaknya pengaruh antara variabel independen terhadap variabel dependen secara bersama-sama (simultan) digunakan uji $\mathrm{f}$. Dari hasil output SPSS dapat dilihat pada tabel ANOVA. nilai $\mathrm{f}_{\text {tabel }}$ sebesar 2,3127dan nilai $f_{\text {hitung }}$ sebesar 21.615serta nilai Sig sebesar 0,000 0,05. hal ini berarti variabel luas tanah, jarak bidang tanah dengan jalan raya, jarak bidang tanah dengan UTM, jarak bidang tanah dengan pasar, legalitas, topografi dan bentuk tanah berpengaruh secara simultan (bersama-sama) terhadap nilai tanah yang berada di sekitar kampus UTM karena nilai $f_{\text {hitung }}>f_{\text {tabel }}$ $(21,615>2,3127)$.

c. Uji t (Uji Secara Parsial)

Untuk mengetahui ada atau tidaknya pengaruh dari masing-masing variabel independen secara individu (sendiri-sendiri), maka menggunakan uji t. Dengan taraf signifikan 0,05 dan nilai df $(n-k)=(40-8)=32$, maka diketahui nilai $t$ tabel sebesar 2,0369 apabila dibandingkan dengan nilai t-hitung, maka hasil yang didapatkan sebagai berikut :

\section{Luas Tanah}

Berdasarkan hasil output SPSS 17.0 diketahui bahwa nilai thitung pada variabel luas tanah sebesar 0,012 dengan nilai sig 0,991. Dengan nilai $t_{\text {tabel }}$ sebesar 2,0369. Maka dapat dilihat bahwa nilai $t_{\text {hitung }}(0,012)<t_{\text {tabel }}(2,0369)$. Hal ini berarti luas tanah secara parsial tidak berpengaruh terhadap nilai tanah di sekitar UTM. Hal ini dikarenakan pada umumnya masyarakat menggunakan tanah disekitar UTM digunakan untuk membangun usaha dengan pola bagunan vertikal atau bertingkat sehingga tidak terlalu membutuhkan tanah yang luas untuk membuat usaha terutama untuk kos.

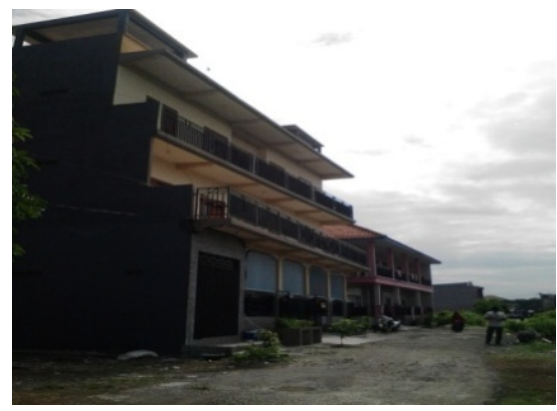

Gambar 1.

\section{Bangunan kos bertingkat}

Hal ini berkebalikan dengan penelitian yang dilakukan oleh Rahayu (2009), dimana hasil penelitiannya menyatakan bahwa variabel luas tanah merupakan salah satu elemen yang menunjukkan tingkat alternatif yang bisa di pilih oleh pemilik oleh-orang-orang yang menguasai tanah, semakin luas tanah semakin banyak alternatif penggunaan tanah dalam berbagai bidang kepentingan, misalnya perdagangan, industri, ataupun perumahan.

\section{Jarak Bidang Tanah dengan Jalan Raya}

Berdasarkan hasil output SPSS 17.0 diketahui bahwa nilai $t_{\text {hitung }}$ pada variabel jarak bidang tanah dengan jalan raya sebesar 3,493 dengan nilai 
sig0,001. Dengan nilai $t_{\text {tabel }}$ sebesar 2,0369. Maka dapat dilihat bahwa nilat $t_{\text {hitung }}$ $(3,493)>t_{\text {tabel }}(2,0369)$. Hal ini berarti jarak bidang tanah dengan jalan raya kabupaten secara parsial berpengaruh terhadap nilai tanah di sekitar UTM.

Bidang tanah yang dekat dengan jalan raya akan memudahkan akses menuju ke berbagai kegiatan ekonomi, sehingga biaya transportasi yang dibutuhkan semakin sedikit. Hal ini sesuai dengan apa yang disebutkan oleh rahayu (2009), lokasi tanah yang jauh dari jalan umum akan menyebabkan semakin jauhnya jarak yang ditempuh dan semakin tingginya biaya transportasi yang di perlukan, hal tersebut akan mempungaruhi turunnya utilitas properti sehingga nilainya juga akan menurun

Variabel jarak bidang tanah dengan jalan raya dengan nilai koefisien sebesar-0,386 menghasikan nilai negatif, semakin jauh dari jalan raya maka harganya akan menurun atau perubahan jarak sebesar $1 \%$ akan menurunkan nilai tanah sebesar $38,6 \% / \mathrm{M}^{2}$ dengan asumsi bahwa luas tanah, jarak bidang tanah dengan UTM, jarak bidang tanah dengan pasar, legalitas, topografi dan bentuk tanah adalah tetap (ceteris paribus).

\section{Jarak Bidang Tanah Dengan UTM}

Berdasarkan hasil output SPSS 17.0 diketahui bahwa nilai $t_{\text {hitung }}$ pada variabel jarak bidang tanah dengan UTM sebesar 2,370 nilai sig 0,024. Dengan nilai $t_{\text {tabel }}$ sebesar 2,0369. Maka dapat dilihat bahwa nilat $t_{\text {hitung }}(2,370)>t_{\text {tabel }}$ $(2,0369)$. Hal ini berarti jarak bidang tanah dengan UTM secara parsial berpengaruh terhadap nilai tanah di sekitar UTM.

Berdirinya kampus UTM di desa telang membawa dampak positif terhadap nilai tanah yang ada disekitarnya. Berbagai jenis usaha mulai dibangun di sekitar kampus UTM untuk memenuhi kebutuhan hidup mahasiswa. Hal tersebut sejalan dengan penelitian Rahayu (2009), yang mengatakan bahwa variabel jarak tanah ke kampus memiliki pengaruh yang signifikan dengan arah yang hubungan negatif terhadap nilai tanah per meter perseginya.

Variabel jarak bidang tanah dengan UTM dengan nilai koefisien sebesar 0.282 menghasikan nilai negatif terhadap nilai tanah yang artinya semakin jauh dengan kampus UTM maka harganya semakin rendah. Nilai koefisien tersebut juga menunjukkan bahwa setiap tambahan jarak ke kampus UTM sebesar $1 \%$ maka akan menurunkan nilai tanah sebesar $28,2 \% / \mathrm{M}^{2}$ dan sebaliknya. dengan asumsi bahwa luas tanah, jarak bidang tanah dengan jalan, jarak bidang tanah dengan pasar, legalitas, topografi dan bentuk tanah adalah tetap (ceteris paribus). jarak bidang tanah dengan pasar.

\section{Jarak Ke Pasar}

Berdasarkan hasil output SPSS 17.0 diketahui bahwa nilai $t_{\text {hitung }}$ pada Variabel jarak bidang tanah dengan pasar sebesar 1.289 , nilai sig 0,207 . Dengan nilai $t_{\text {tabel }}$ sebesar 1,993464 . Maka dapat dilihat bahwa nilat $t_{\text {hitung }}(1,289)<t_{\text {tabel }}$ $(2,0369)$. Hal ini berarti jarak bidang tanah dengan pasar secara parsial tidak berpengaruh secara signifikan terhadap nilai tanah di sekitar UTM.

Jarak bidang tanah tidak berpengaruh signifikan terhadap jarak pasar. Karena di desa Telang sudah banyak berbagai jenis usaha seperti mini market yang menjual bebagai macam kebutuhan yang mampu memenuhi kebutuhan hidup mahasiswa dan masyarakat disana. Sehingga, untuk memenuhi kebutuhan hidup sehari-hari tidak perlu pergi kepasar. 


\section{Legalitas Tanah}

Berdasarkan hasil output SPSS 17.0 diketahui bahwa nilai $t_{\text {hitung }}$ pada legalitas tanah sebesar 7,162 nilai sig 0,000. Dengan nilai $t_{\text {tabel }}$ sebesar 2,0369. Maka dapat dilihat bahwa nilai $t_{\text {hitung }}(7,162)>t_{\text {tabel }}(2,0369)$. Hal ini berarti legalitas tanah secara parsial berpengaruh terhadap nilai tanah di sekitar UTM.

Legalitas sangat penting sebagai bukti kepemilikan tanah secara hukum. Pada penelitian Rostiningsih dkk (2013), juga menyatkan bahwa 100\% responden menyatakan lokasi adalah faktor paling dan $70 \%$ responden menyatakan bahwa sertifikat tanah merupakan faktor penting. Tanah di sekitar UTM memang sangat memiliki prospek sebagai pengembangan usaha mengingat jumlah mahasiswa yang semkin banyak setiap tahunnya. Luas tanah yang sudah memiliki sertifikat hak milik berdasarkan data BPN Bangkalan 2015 adalah $3843709 \mathrm{M}^{2}$.

Dari total 40 responden hanya $20 \%$ yang belum memiliki sertifikat. Dalam artian respondentersebut belum memiliki sertifikat resmi terbaru yang di keluarkan oleh BPN daerah Bangkalan akan tetapi, hanya memiliki surat yang dikeluarkan pada tahun 1985 yang biasa disebut patok D atau koher(dalam bahasa lokal). Surat tanah yang dimiliki tersebut tidak sah dimata hukum negara. Sehingga responden tersebut dianggap belum memiliki sertifikat,

Variabel legalitas, nilai koefisien sebesar 0.704 menghasikan nilai positif, hal ini berarti perubahan peningkatan legalitas sebesar $1 \%$ akan meningkatkan nilai tanah sebesar $70,4 \% / \mathrm{M}^{2}$ dengan asumsi bahwa luas tanah, jarak bidang tanah dengan jalan, jarak bidang tanah dengan UTM, jarak bidang tanah dengan pasar, topografi dan bentuk tanah adalah tetap (ceteris paribus).

\section{Topografi Tanah}

Berdasarkan hasil output SPSS 17.0 diketahui bahwa nilai $t_{\text {hitung }}$ pada variabel topografi tanah sebesar 3.460 nilai sig 0,002 . Dengan nilai $t_{\text {tabel }}$ sebesar 2,0369 . Maka dapat dilihat bahwa nilai $t_{\text {hitung }}(3.460)>t_{\text {tabel }}(2,0369)$. Hal ini berarti topografi tanah secara parsial berpengaruh terhadap nilai tanah di sekitar UTM.

Tanah yang memiliki topografi datar akan lebih mudah untuk dibangun. Rata-rata topografi tanah dari responden adalah datar Berbeda dengan tanah yang memiliki topografi yang landai atau berbukit. Topografi landai cenderung berpotensi akan banjir apabila musim penghujan, sehingga nilai tanahnya akan menurun.
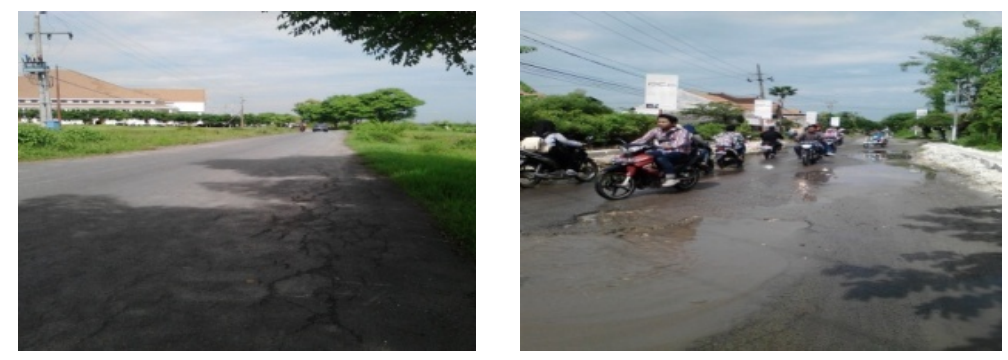

Gambar 2.

Keadaan topografi Datar dan Landai

Variabel topografi tanah dengan pasar dengan nilai koefisien sebesar 0,704 menghasikan nilai positif, hal ini berarti perubahan topografi sebesar $1 \%$ akan menaikkan nilai tanah sebesar $70,4 \% / \mathrm{M}^{2}$ atau semakin datar 
harganyasemakin tinggi dengan asumsi bahwa luas tanah, jarak bidang tanah dengan jalan, jarak bidang tanah dengan UTM, jarak bidang tanah dengan pasar, legalias dan bentuk tanah adalah tetap (cateris paribus).

\section{Bentuk tanah}

Berdasarkan hasil output SPSS 17.0 diketahui bahwa nilai t hitung pada variabel bentuk tanah sebesar 2,813 nilai sig 0,008. Dengan nilai $t_{\text {tabel }}$ sebesar 2,0369 . Maka dapat dilihat bahwa nilai $t_{\text {hitung }}(2,813)>t_{\text {tabel }}(2,0369)$. Hal ini berarti bentuk tanah secara parsial berpengaruh terhadap nilai tanah di sekitar UTM.

Bentuk tanah tanah akan mempengaruhi bentuk bangunan yang akan di bangun diatasnya yang akan dijadikan sebagai penentu arah muka bangunan. Hal tersebut sejalan dengan penelitian yang dilakukan oleh Rositaningsih dkk (2013), mengatakan bahwa faktor bentuk tanah yang paling diminati pembelian properti di surabaya adalah bentuk tanah persegi panjang misalnya dengan ukuran $10 \times 20,12 \times 24,15 \times 30$.

Variabel bentuk tanah dengan pasar dengan nilai koefisien sebesar 0.260 menghasikan nilai negatif, hal ini berarti perubahan bentuk (selain persegi panjang) sebesar $1 \%$ akan menurunkan nilai tanah sebesar $26,0 \% / \mathrm{M}^{2}$ dengan asumsi bahwa luas tanah, jarak bidang tanah dengan jalan, jarak bidang tanah dengan UTM, jarak bidang tanah dengan pasar, legalias dan topografi adalah tetap (ceteris paribus)

\section{PENUTUP}

Berdasarkan hasil dan pembahasan, maka dapat disimpulkan bahwa penggunaan tanah di sekitar kampus Universitas Trunojoyo Madura sebagian besar masih digunakan sebagai kos dan pemukiman. Terdapat perbedaan signifikan nilai tanah kawasan UTM dan non UTM. Faktor-faktor yang mempengaruhi nilai tanah terhadap keberadaan kampus UTM secara signifikan adalah variabel jarak bidang tanah dengan jalan raya utama, jarak bidang tanah dengan kampus UTM dan legalitas tanah, topografi tanah, dan bentuk tanah. Sementara variabel yang tidak signifikan adalah luas tanah, jarak dengan pasar.

\section{DAFTAR PUSTAKA}

Adhi, Hendra Ibnu, Dkk. 2015. Pemetaan Zona Nilai Tanah Untuk Menentukan Nilai Jual Objek Pajak (Njop) Menggunakan Sistem Informasi Geografis. Jurnal Geodesi Undip 4(3): 66-77.

Astuti, Anastasia, Dkk. 2015.Analisis Pengaruh Perubahan Nilai Jual Tanah Terhadap Zona Nilai Tanah. Jurnal Geodesi Undip 4 (1): 72-84.

Central Intelligence Agency (CIA). 2015. The World Factbook.https://www.cia.gov. Diakses tanggal 26 Oktober 2015.

Ghozali, Imam. 2013. Aplikasi Analisis Multivariat dengan Program IMB SPSS21. Semarang: Badan Penerbit Universitas Diponogoro.

Haughwout, Andrew, Dkk. 2008. The Price Of Land In The New York Metropolitan Area. Journal Current Issues In Economics and Finance14(3): 1-7 
Portnov, Boris A. 2005. Factors Affecting Housing Modifications and Housing Pricing : A Case Study of Four Residential Neighborhoods in Haifa Israel. JRR 27(4): 372-407

Rahayu, Heffy Christya. 2009. Analisa Nilai Tanah Terhadap Lingkungan Kampus Politeknik Pasir Pengaraian. Jurnal APTEK 1(1): 61-69

Rostiningsih, Silvia. 2013. Aplikasi Sistem Pendukung Keputusan Bidang Properti Di Surabaya Dengan Metode Hold's Double Exponential Smoothing Dan Trend Linear. Seminar Nasional ke-8Universitas Kristen Petra.

Santoso, Singgih. 2014. Statistik Parametrik: konsep dan aplikasi dengan SPSS. Jakarta: PT. Elex Media Komputindo.

Sarjono, Haryadi dan Winda J. 2011. SPSS Vs Lisrel sebuah pengantar, Aplikasi Untuk riset. Salemba empat. Jakarta

Setiawan, Ikhsan. 2006.Faktor-Faktor Yang Mempengaruhi Perubahan Nilai Tanah Dan Bangunan Pada Suatu Properti (Kasus: Perumahan Galaxi Bumi Permai, Surabaya). Jurnal NEUTRON 6(2): 137-154

Siregar, Syafaruddin. 2005. Statistik Terapan untuk Penelitian. Jakarta: PT Gramedia Widiasarana Indonesia.

Sugiono. 2009. Metode Penelitian Bisnis. Bandung: Alfabeta.

Suparmoko. M.2002. buku pedoman Penilaian Ekonomi;Sumberdaya Alam \& Lingkungan.Yogyakarta: BPFE.

Sutawijaya, Andrian. 2004. Analisis Faktor-Faktor Yang Mempengaruhi Nilai Tanah Sebagai Dasar Penilaian Nilai Jual Obyek Pajak (Njop) PBB Di Kota Semarang. Jurnal Ekonomi Pembangunan9(1): 65-78.

Zuhriyah, Amanatuz dan Ihsannudin. 2013.Dampak Keberadaan Jembatan Suramadu Terhadap Nilai Tanah Di Wilayah Kaki Jembatan Sisi Madura. Jurnal Agriekonomika2(1): 59-66. 